\title{
Çankırı Sarıçam Ormanlarında Diprion pini L. (Hymenoptera: Diprionidae)'nin Feromon Tuzakları Yardımıyla Popülasyon Seyrinin Belirlenmesi ${ }^{*}$
}

\author{
Ziya ŞiMŞEK*, Yalçın KONDUR \\ Çankırı Karatekin Üniversitesi, Orman Fakültesi, 18200, Çankırı/Türkiye \\ *Sorumlu Yazar: ziyasimsek@karatekin.edu.tr
}

Geliş tarihi: 09.11.2016

Kabul tarihi: 07.03.2017

Özet : Çalışmalar, Kalfat (Çankırı, Orta)'ta yaklaşık 1100 ha, Kurşunlu (Çankırı)'da 1 ha büyüklükteki Sarıçam (Pinus sylvestris L.) orman alanlarında, Diprion pini L. (Hymenoptera: Diprionidae)'nin türe özgü eşeysel çekici feromonu [(2S,3R,7R)-3,7-dimetil-2-tridekanol) asetat ve propionat1] ile Lund-I tipi tuzak setleri kullanılarak yürütülmüştür. Elde edilen bulgulara göre, D. pini’nin 6 larva dönemi geçirerek yılda bir döl verdiği; erginlerin birbiriyle iç içe iki uçuş periyodunun bulunduğu ve ergin uçuşlarının 50-80 gün sürdüğü, anlaşılmıştır. Feromon tuzaklarda 2004-2006 yılları arasında Kalfat çalışma alanında yıllar itibarıyla sırasıyla 4434, 430 ve 437 adet; Kurşunlu'da ise 1175, 279 ve 43 adet olmak üzere 3 yılda toplam 6798 adet D.pini ergini yakalanmıştır. Buna göre; D. pini’nin türe özgü feromon tuzaklarla popülasyon seyrinin Türkiye'de de izlenebileceği ilk kez ortaya konulmuştur. Aynı çalışmada, feromon tuzakları kullanılmak suretiyle, izole sarıçam alanlarında D. pini popülasyon yoğunluğunun azaltılabileceği belirlenmiştir.

Anahtar Kelimeler: Diprion pini, Sarıçam, Pinus sylvestris, Çankırı, feromon

\section{Determination of Flight Period of Diprion pini L. (Hymenopera: Diprionidae) in Çankırı Scots Pine Forests via Pheromone Traps}

Abstract: Studies were carried out in Scots pine (Pinus sylvestris L.) forest areas of approximately 1100 ha in Kalfat (Çankırı, Orta) and 1 ha Kurşunlu (Çankırı) with species-specific sex pheromone [(2S,3R,7R)-3,7-dimethyl-2-tridecanol) acetate and propionate] of Diprion pini L. (Hymenoptera: Diprionidae) and Lund-I type trap sets. Results show that D. pini has 6 instars and one generation, and adult flights continued 50-80 days as two intersecting waves. In this study carried out, a total of 6798 D.pini adults have been captured during 3 year-study period which were 4434, 430 and 437 D. pini adults in Kalfat area and 1175, 279 and 43 D. pini adults in Kurşunlu area between 2004 and 2006 respectively. These results show that monitoring of $D$. pini via species-specific pheromone traps may be utilized in Turkey for the first time. Also, application of pheromone traps of D.pini may decrease the population density.

Keywords: Diprion pini, Scots pine, Pinus sylvestris, Çankırı, pheromone

\section{Giriş}

Türkiye'de toplam 10,587,987 ha normal, $10,155,135$ ha bozuk orman alanının sirasiyla $\% 10.73 \quad(1,136,000$ ha) ve \%8.9'u (1,316,000 ha) Orta Anadolu Bölgesi'nde bulunmaktadır (Konukçu, 1999). Bu bölgedeki normal orman alanının $(1,135,349$ ha) $\% 7.7$ 'si ise $(87,812$ ha) çalışma alanı olan Çankırı'da ilimizde bulunmaktadır. Söz konusu ildeki normal orman alanının \%35'i ise $(30,728$ ha) Ilgaz ormanlarında yer almaktadır. Çankırı'daki ormanların yaklaşık \%60'1 Sarıçam (Pinus sylvestris L.) ile Karaçam (Pinus nigra Arnold.)'dan ibarettir.

Türkiye'de bazı alanlarda ibrelilere yer verilerek saf meşcere kurulması, plantasyonların ormancılık açısından uygun olmayan alanlarda yapılmış olması, son yıllarda olumsuz iklim koşulları (yağış azlığı, sıcaklığın artması), küresel 1sınma, toprağın giderek fakirleşmesi gibi olumsuz koşullar; gerek orman ve gerekse fidanliklarda bulunan ağaçları biyotik ve abiyotik faktörlere karşı duyarlı hale gelmesine neden olmuştur (Öner ve ark., 2010). Bunun sonucunda, Çankırı orman alanlarında çok sayıda hastalık etmenleri ile zararlı böceklerin periyodik olarak salgın yapma eğilimine girdiği gözlenmiştir (Şimşek ve Kondur, 2006). Bu zararlilardan birisi de bitki dokusuyla beslenen diprionidlerden olan çalı antenli çam yaprakarısı [Diprion pini (L.) (Hymenoptera: Diprionidae)] olup Çankırı'nın Orta ilçesi Kalfat Beldesi ile

\footnotetext{
* Bu çalışma TÜBİTAK TAVAG tarafindan desteklenen TOGTAG-3244 (1030104) no’lu araştırma projesinin bir bölümüdür.
} 
Kurşunlu ilçesinde özellikle yaşları 10-20 arasında değişen sarıçam orman plantasyonlarında yaklaşık 1100 ha alanda ibreleri yiyerek 2000'li yıllarda epidemi yaptığ1 saptanmıştır (Şimşek, 2004). Bunun üzerine, yapılan literatür taramalarında değişik ülkelerde, D. pini'nin cinsel çekici feromonun yaklaşık olarak son 15 yıldır üretilip kullanılmaya başlandığı; söz konusu böceğin zarar durumu, biyo-ekolojisi, türe özgü feromon tuzakları yardımıyla uçuş seyrinin izlendiği, iklim verileriyle olan ilişkilerinden yararlanılarak tahmin ve erken uyarı üzerinde ayrıntılı çalışmalar yapıldığ anlaşılmıștır (Daskalova ve Kitin, 1973; Moiseenki ve Kozhevnikov, 1976; Pilt, 1986; Song ve ark., 1986; Chen ve ark., 1987; Sharov, 1987; Supatashvili, 1990; Malinowski ve Glowachka, 1992; Glowachka ve Malinowski, 1994; David ve ark., 1996; Klimetzek ve ark., 1997; Anderbrandt ve ark., 1998; LyytikainenSaarenmaa ve ark., 1999; Herz ve ark., 2000; Lyytikainen-Saarenmaa ve ark., 2001). Türkiye'de kitlesel tuzaklama yönteminin orman alanında zararlı olan bazı türlere, özellikle kabuk böceklerine karşı 1982 yılından bu yana kullanılarak başarılı sonuçlar alınmasına karşın (Serez, 1987) D. pini mücadelesinde kullanıldığına dair bir kayda rastlanılmamıştır.

Çankırı'da özellikle sarıçam plantasyonlarında $D$. pini'nin epidemi yapması üzerine zararlının feromon tuzakları ile popülasyon seyrinin izlenmesi amaciyla ele alınan bu çalışma, 2004-2006 yılları arasında 3 y1l süreyle yürütülmüştür.

\section{Materyal ve Yöntem}

Çalışmalar; Çankırı ili Orta ilçesinin Kalfat beldesi yakınlarındaki $1340 \mathrm{~m}$ yükseltide, 30-40 yaşlı ve 3 kapalı (yaklaşık 1100 ha), Kurşunlu ilçesinde ise $1204 \mathrm{~m}$ yükseltide, 15-20 yaşl1, 1-2 kapalı (yaklaşık 1 ha) ve çevresinde başka orman alanı bulunmayan, plantasyonla tesis edilmiş iki Sarıçam meşceresinde 3 yıl süreyle yürütülmüştür.
Çalışmada D. pini'nin uçuş seyrinin belirlenmesinde, zararlının türe özgü feromonu [(2S,3R,7R)-3,7-dimetil-2tridekanol) asetat ve propionat1] ile Lund-I tipi tuzak setleri kullanılmıştır (Şekil 1a). $D$. pini'nin feromon tuzakları, çalışma alanları olan Kurşunlu ile Kalfat orman alanlarında, güney-güneydoğu bakılarda olacak şekilde 50 'şer metre araliklarla, yerden $1,5 \mathrm{~m}$ yüksekliğe 5'er adet olmak üzere sıra halinde asılmış ve içerisine dispenser'ları ile yapışkan tablaları yerleştirilmiştir (Herz ve ark., 2000; Wassgren ve Bergström, 2000). Her iki çalışma alanında da tuzaklar, ergin uçuşları başlamadan (hava sicaklığ $15^{\circ} \mathrm{C}$ 'nin üzerine çıkmadan) önce (Kalfat çalışma alanında sirasiyla 20.05.2004, 31.05.2005 ve 22.05.2006 tarihlerinde; Kurşunlu çalışma alanında ise yine sirasiyla 01.06.2004, 30.05.2005 ve 22.05.2006 tarihlerinde) yerleştirilmiştir.

Tuzaklar, yerleştirildikten bir hafta sonra kontrol edilmiş; böceklerin yakalandığ 1 tespit edilince, feromon tuzakların içindeki yapışkan tablalar yerlerinden alındıktan sonra yerine yeni bir yapışkan tabla yerleştirilmiştir. Feromon tuzaktan alınmış olan eski yapışkan tabla, buz kabında laboratuara getirilmiştir. Laboratuarda, stereo-mikroskop altında yapilan incelemelerde, yapışkan tabla üzerindeki erginler sayılarak kaydedilmiştir (Şekil 1b). Çalışma süresince, 6 haftada bir olmak üzere dispenser'lar yenileriyle değiştirilmiştir. Feromon tuzaklar, ergin uçuşlarının tamamlandığından emin olmak için 2 hafta süreyle yerlerinden alınmamıştır.

Meteorolojik veriler, Devlet Meteoroloji İşleri Genel Müdürlügünün çalışma alanına en yakın olan meteoroloji istasyonundan (Şabanözü) temin edilmiştir. Feromon tuzaklarda yakalanan böcekler sayılarak iklim verileriyle ilişkilendirilmiş, Excel yazılımı yardımıyla tablo ve şekil olarak düzenlenip aralarındaki ilişkiler araştırılmıştır. İstatistik analizlerde, ANOVA testi uygulanmıştır. 

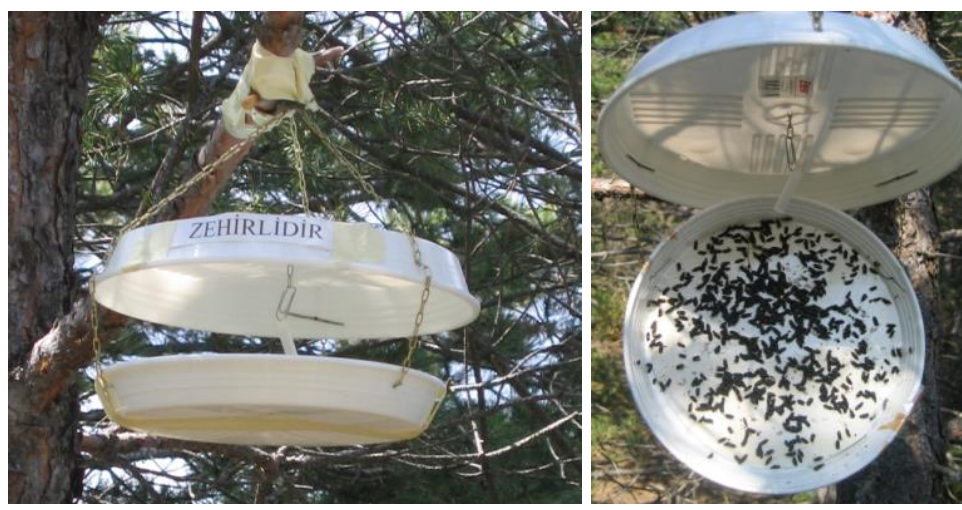

Şekil 1. Çankırı'da Sarıçam (Pinus sylvestris L.) dalına asılmış Diprion pini L. feromon tuzağı (a) ile feromon tuzakta yakalanmış $D$. pini erginleri (b)

\section{Bulgular ve Tartışma}

Feromon tuzaklarda D. pini'nin popülasyon seyrinin izlenmesine ilişkin bulgular Tablo 1-3 ile Şekil 2-7'de; zararlının y1llara göre değişim durumu ise Şekil 8'de verilmişstir.

\section{Feromon Tuzaklarda 2004 Yılında} Yakalanan Diprion pini L. Sayıları

Kalfat (Orta) ile Kurşunlu sarıçam orman alanlarında $D$. pini erginlerinin feromon tuzaklarda yakalanmalarına ait sonuçlar Tablo 1'de; bunlara ait veriler ise sirasiyla Şekil 2 ve 3'te, iklim verileriyle birlikte, verilmiştir.

Tablo 1. 2004 Yılında Çankırı'nın Orta (Kalfat) ve Kurşunlu ilçeleri orman alanlarında feromon tuzaklarda yakalanan Diprion pini L. ergini sayıları

\begin{tabular}{|c|c|c|c|c|c|c|c|c|c|c|c|c|c|}
\hline \multirow[t]{2}{*}{ Tarih } & \multicolumn{5}{|c|}{$\begin{array}{l}\text { KALFAT } \\
\text { Tuzak No }\end{array}$} & \multirow[t]{2}{*}{ Toplam } & \multirow[t]{2}{*}{ Tarih } & \multicolumn{5}{|c|}{$\begin{array}{c}\text { KURŞUNLU } \\
\text { Tuzak No }\end{array}$} & \multirow[t]{2}{*}{ Toplam } \\
\hline & 1 & 2 & 3 & 4 & 5 & & & 1 & 2 & 3 & 4 & 5 & \\
\hline 08.06 .2004 & 3 & 2 & 1 & 1 & 0 & 7 & 10.06 .2004 & 1 & 0 & 0 & 2 & 0 & 3 \\
\hline 15.06 .2004 & 21 & 15 & 17 & 3 & 13 & 69 & 17.06 .2004 & 7 & 15 & 17 & 24 & 12 & 75 \\
\hline 22.06.2004 & 151 & 18 & 62 & 28 & 28 & 287 & 25.06.2004 & 5 & 11 & 19 & 17 & 7 & 59 \\
\hline 01.07 .2004 & 123 & 27 & 97 & 21 & 26 & 294 & 28.06 .2004 & 5 & 5 & 3 & 5 & 4 & 22 \\
\hline 08.07 .2004 & 79 & 39 & 128 & 29 & 32 & 307 & 06.07 .2004 & 2 & 9 & 7 & 9 & 10 & 37 \\
\hline 15.07.2004 & 124 & 24 & 83 & 17 & 24 & 272 & 12.07.2004 & 0 & 3 & 4 & 0 & 5 & 12 \\
\hline 22.07.2004 & 103 & 23 & 109 & 29 & 19 & 283 & 20.07 .2004 & 1 & 0 & 3 & 4 & 7 & 15 \\
\hline 29.07.2004 & 490 & 118 & 278 & 116 & 175 & 1177 & 26.07.2004 & 6 & 14 & 9 & 7 & 17 & 53 \\
\hline 05.08.2004 & 549 & 189 & 337 & 172 & 288 & 1535 & 03.08.2004 & 93 & 157 & 156 & 197 & 205 & 808 \\
\hline 12.08.2004 & 81 & 23 & 35 & 4 & 48 & 191 & 09.08 .2004 & 9 & 14 & 11 & 8 & 17 & 59 \\
\hline 19.08.2004 & 3 & 0 & 2 & 3 & 4 & 12 & 17.08 .2004 & 3 & 6 & 9 & 5 & 9 & 32 \\
\hline 26.08 .2004 & 0 & 0 & 0 & 0 & 0 & 0 & 24.08 .2004 & 0 & 0 & 0 & 0 & 0 & 0 \\
\hline 02.09 .2004 & 0 & 0 & 0 & 0 & 0 & 0 & 31.08 .2004 & 0 & 0 & 0 & 0 & 0 & 0 \\
\hline TOPLAM & 1727 & 478 & 1149 & 423 & 657 & 4434 & TOPLAM & 132 & 234 & 238 & 278 & 293 & 1175 \\
\hline
\end{tabular}



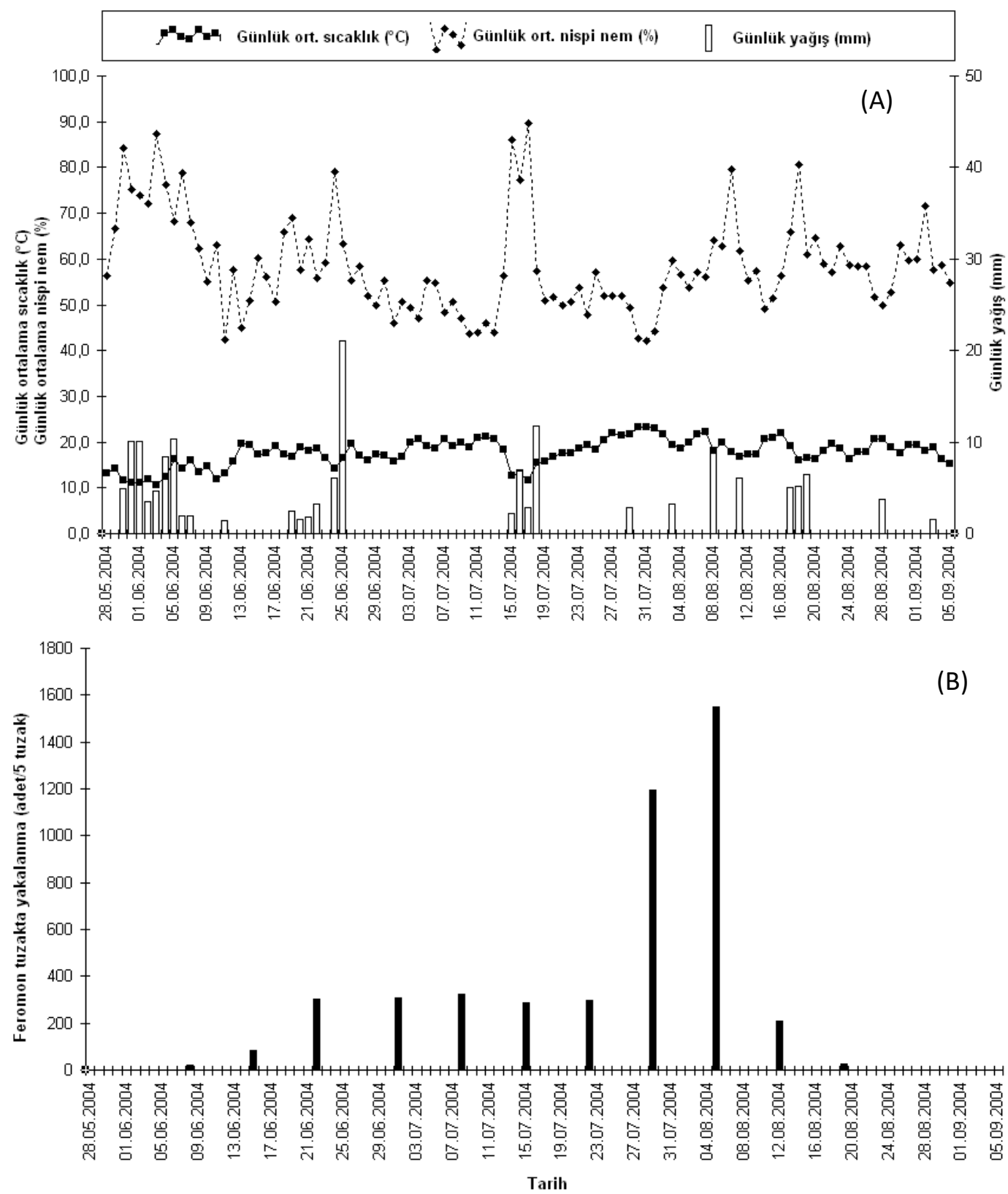

Şekil 2. Çankırı (Orta, Kalfat)'da 2004 yılında ait meteorolojik veriler (A) ile çalışma alanındaki feromon tuzaklarda yakalanan Diprion pini L. ergini sayıları (B)

Tablo 1 incelendiğinde Kalfat (Orta)'taki feromon tuzaklarda 08.06.2004 tarihinde $D$. pini ergini ilk kez yakalandığ tarihinde son bulduğu anlaşılmaktadır. Yoğun yakalanmaların, uçuş periyodunun 8 . (29.7.2004) ve 9. (05.08.2004) haftasinda, sirasiyla toplam 1177 ve 1535 adet yakalandığı anlaşılmaktadır. Buna göre, Kalfat'ta uçuş periyodu 80 gün sürmekle birlikte, yoğun uçuşların 2 hafta içerisinde gerçekleştiği söylenebilir. Buna göre, 2004 yllında yürütülen çalışma sonucunda oldukça yoğun yakalanmanın gerçekleștiği de (4434 adet) aynı tablodan anlaşılmaktadır.

Yine Tablo 1 incelendiğinde; Kurşunlu'daki feromon tuzaklarında 10.06.2004 tarihinde ilk yakalanmanın gerçekleştiği, 17.08.2004 tarihinde son bulduğu görülmektedir. Toplam 808 adet erginin yakalandığ 1 uçuş periyodunun 9 . haftasinda (03.08.2004) doruk noktasina ulaştığı anlaşılmaktadır. Buna göre, Kurşunlu'da uçuş periyodu 76 gün sürmekle birlikte, yoğun uçuşların 1 hafta içerisinde 
gerçekleştiği söylenebilir. Sözü edilen alanda yürütülen çalışma sonucunda toplam 1175 adet gibi oldukça yoğun yakalanmanın gerçekleştiği de aynı tabloda görülmektedir.

Tablo 1 ile Şekil 2(A) birlikte incelendiğinde, çalışma alanında ilk kez $D$. pini ergini yakalandığı sırada günlük ortalama sicaklığın $13.5^{\circ} \mathrm{C}$ ve nispi nemin $\%$ 62.3 olduğu; feromon tuzaklarında yakalanmaların gerçekleştiği periyotta ortalama sicaklığı $11.7-23.3^{\circ} \mathrm{C}$ arasında, nispi nemin ise \%42.0-89.7 arasında değiştiği anlaşılmaktadır. Söz konusu çalışma alanında yoğun ergin yakalanmaları sirasında (1177 ve 1535 adet) ortalama sicaklığın 18.4$23.3^{\circ} \mathrm{C}$; nispi nemin ise \%42.0-59.7 arasinda değiştiği, D.pini uçuşlarının devam ettiği süre boyunca toplam yağış miktarının ise $130.1 \mathrm{~mm}$ olduğu, yoğun uçuşların yağışlı havalarda da gerçekleştiği anlaşılmaktadır (Şekil 2A).
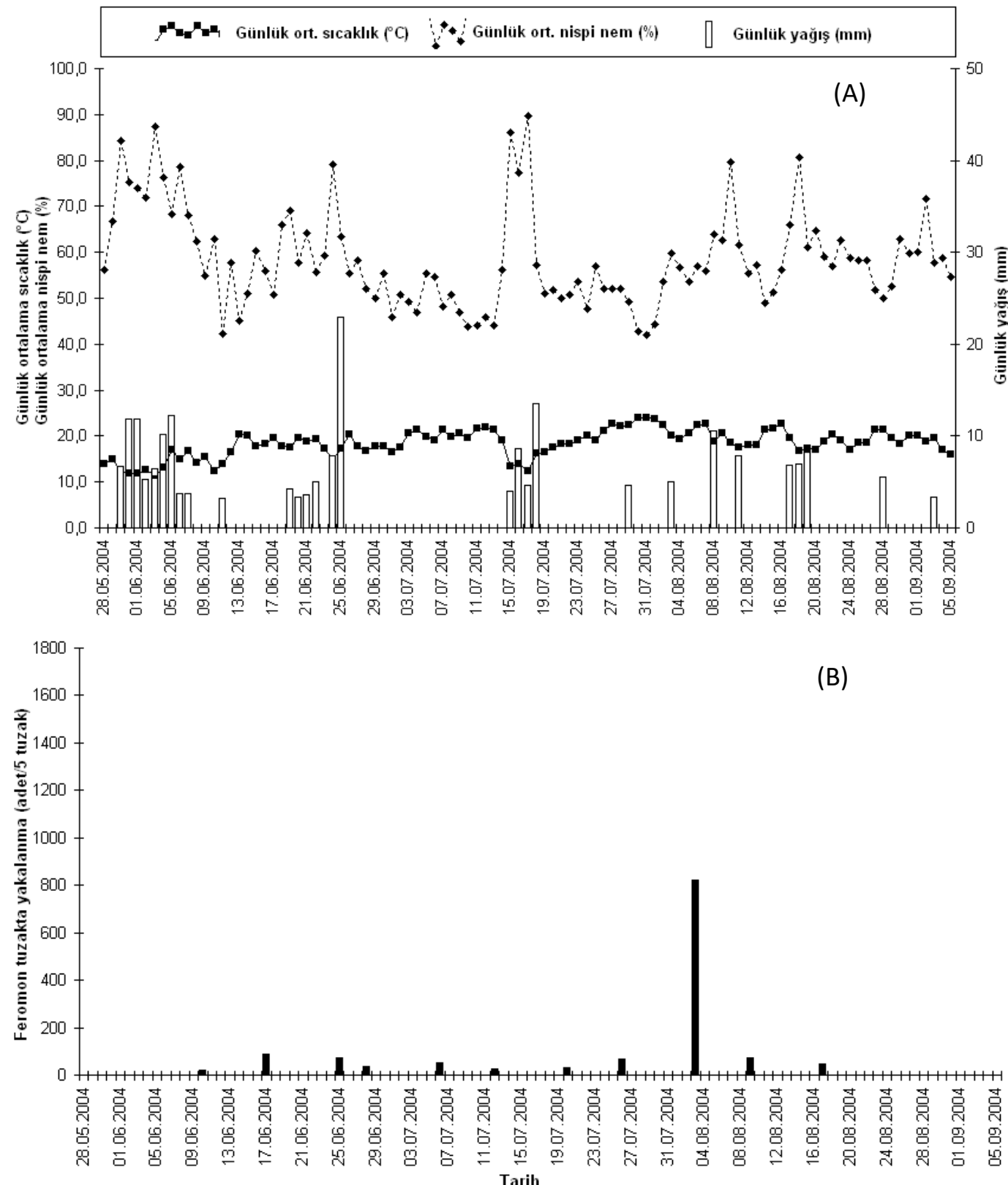

Şekil 3. Çankırı (Kurşunlu)'da 2004 yılında ait meteorolojik veriler (A) ile çalışma alanındaki feromon tuzaklarda yakalanan Diprion pini L. ergini sayıları (B) 
Kurşunlu'da ilk kez D. pini ergini yakalandığ 1 sırada günlük ortalama sıcaklığın $12.5^{\circ} \mathrm{C}$ ve nispi nemin \% 63 olduğu; feromon tuzaklarda yakalanmaların gerçekleştiği periyotta ortalama sicaklığın $11-24^{\circ} \mathrm{C}$ arasinda, nispi nemin ise \% 42-90 arasinda değiştiği anlaşılmaktadır (Şekil 3A). Söz konusu çalışma alanında en yoğun ergin yakalanmaları sirasında (808 adet) ortalama sicaklığın $20-24^{\circ} \mathrm{C}$; nispi nemin ise $\% 42-60$ arasında değiştiği, $D$. pini uçuşlarının devam ettiği süre boyunca toplam yağış miktarının $144.2 \mathrm{~mm}$ olduğu, yağışlı havalarda da uçuşların gerçekleștiği anlaşılmaktadır (Şekil 3A, B).

Şekil 2 ile 3 beraber değerlendirildiğinde, hem Kalfat'ta hem de Kurşunlu'da hava sıcaklığının ortalama $13^{\circ} \mathrm{C}$ 'ye ulaşmasıyla uçuşların başladığı ve yoğun uçuşların aynı tarihlerde gerçekleştiği anlaşılmaktadır. Söz konusu dönemde ortalama sicaklik 11$24.0^{\circ} \mathrm{C}$; nispi nemin ise $\% 42-90$ arasinda olduğu (Şekil 2A, 3A); D. pini erginlerinin birbiri içerisine geçmiş halde iki uçuş periyodunun bulunduğu; ergin uçuşlarının birinci uçuş periyodunda oldukça zayıf olduğu (Kalfat çalışma alanında 08.06.200422.07.2004; Kurşunlu çalışma alanında ise 10.06.2004-12.07.2004 tarihleri arasında), ikinci uçuş periyodunda ise yoğun ergin uçuşlarının gerçekleştiği (Kalfat çalışma alanında 22.07.2004-19.08.2004; Kurşunlu çalışma alanında ise 12.07.2004-19.08.2004 tarihleri arasında) anlaşılmıştır (Şekil 2B, 2B). Buna göre, feromon tuzaklarda Kalfat (4434 adet) ve Kurşunlu (1175 adet) orman alanlarında toplam 5609 adet $D$. pini ergininin yakalandı̆̆ı; yakalanmaların 8 . haftasinda Kalfat'ta, 9. haftasinda ise Kurşunlu'da doruk noktasına ulaştığg ve uçuş periyodunun yaklaşık 80 gün sürdüğü belirlenmiştir.

Feromon Tuzaklarda 2005 Yılında Yakalanan Diprion pini L. Sayıları

Kalfat (Orta) ile Kurşunlu sarıçam orman alanlarında yapılan çalışmada, D.pini erginlerinin feromon tuzaklarda yakalanmalarına ait sonuçlar Tablo 2'de; bunlara ait veriler ise sırasıyla Şekil 4 ve 5 'te, iklim verileriyle birlikte verilmiştir.

Tablo 2. 2005 Yılında Çankırı'nın Orta (Kalfat) ve Kurşunlu ilçeleri orman alanlarında feromon tuzaklarda yakalanan Diprion pini L. ergini sayıları

\begin{tabular}{|c|c|c|c|c|c|c|c|c|c|c|c|c|c|}
\hline \multirow[t]{2}{*}{ Tarih } & \multicolumn{5}{|c|}{$\begin{array}{l}\text { KALFAT } \\
\text { Tuzak No }\end{array}$} & \multirow[t]{2}{*}{ Toplam } & \multirow[t]{2}{*}{ Tarih } & \multicolumn{5}{|c|}{$\begin{array}{c}\text { KURŞUNLU } \\
\text { Tuzak No }\end{array}$} & \multirow[t]{2}{*}{ Toplam } \\
\hline & 1 & 2 & 3 & 4 & 5 & & & 1 & 2 & 3 & 4 & 5 & \\
\hline 14.06.2005 & 0 & 0 & 0 & 0 & 0 & 0 & 13.06 .2005 & 3 & 2 & 2 & 0 & 1 & 8 \\
\hline 21.06 .2005 & 0 & 0 & 0 & 0 & 0 & 0 & 20.06.2005 & 2 & 0 & 3 & 5 & 0 & 10 \\
\hline 29.06 .2005 & 0 & 1 & 1 & 0 & 0 & 2 & 28.06.2005 & 4 & 0 & 4 & 0 & 0 & 8 \\
\hline 05.07.2005 & 0 & 0 & 1 & 0 & 0 & 1 & 04.07 .2005 & 1 & 1 & 0 & 1 & 0 & 3 \\
\hline 12.07.2005 & 1 & 1 & 0 & 5 & 2 & 9 & 11.07.2005 & 2 & 2 & 0 & 0 & 0 & 4 \\
\hline 19.07.2005 & 0 & 3 & 0 & 2 & 1 & 6 & 18.07.2005 & 0 & 1 & 0 & 1 & 0 & 2 \\
\hline 26.07 .2005 & 0 & 32 & 2 & 15 & 7 & 56 & 25.07.2005 & 1 & 2 & 0 & 2 & 0 & 5 \\
\hline 02.08.2005 & 9 & 119 & 36 & 79 & 39 & 282 & 01.08 .2005 & 8 & 2 & 16 & 11 & 8 & 45 \\
\hline 09.08 .2005 & 0 & 9 & 4 & 37 & 13 & 63 & 08.08.2005 & 36 & 8 & 56 & 41 & 37 & 178 \\
\hline 16.08 .2005 & 1 & 1 & 0 & 7 & 2 & 11 & 15.08 .2005 & 7 & 0 & 2 & 3 & 2 & 14 \\
\hline 23.08 .2005 & 0 & 0 & 0 & 0 & 0 & 0 & 22.08 .2005 & 0 & 1 & 0 & 1 & 0 & 2 \\
\hline 01.09 .2005 & 0 & 0 & 0 & 0 & 0 & 0 & 31.08 .2005 & 0 & 0 & 0 & 0 & 0 & 0 \\
\hline TOPLAM & 11 & 166 & 44 & 145 & 64 & 430 & TOPLAM & 64 & 19 & 83 & 65 & 48 & 279 \\
\hline
\end{tabular}

Tablo 2 incelendiğinde Kalfat (Orta)'taki feromon tuzaklarda 29.06.2005 tarihinde ilk kez D. pini ergini yakalandığı ve 16.08.2005 tarihinde sona erdiği görülmektedir. Toplam 282 bireyin yakalandığı uçuş periyodunun 6.haftasında (02.08.20015) doruk noktasına ulaştığı görülmektedir. Buna göre, uçuşların 47 gün sürdüğü ve toplam 430 adet $D$. pini’nin yakalandığı anlaşılmaktadır. 
Yine, $\quad$ Tablo 2 incelendiğinde; Kurşunlu'daki feromon tuzaklarda ilk kez 13.06.2004 tarihinde D. pini ergininin yakalandığ1 ve 22.08.2004 tarihinde son bulduğu görülmektedir. Aynı yörede toplam
178 bireyin yakalandığ 1 uçuş periyodunun 9 . haftasinda (08.08.2004) doruk noktasina ulaştığ 1 , uçuş periyodunun 76 gün sürdüğü, bu periyotta toplam 279 adet D. pini'nin yakalandığı anlaşılmaktadır.
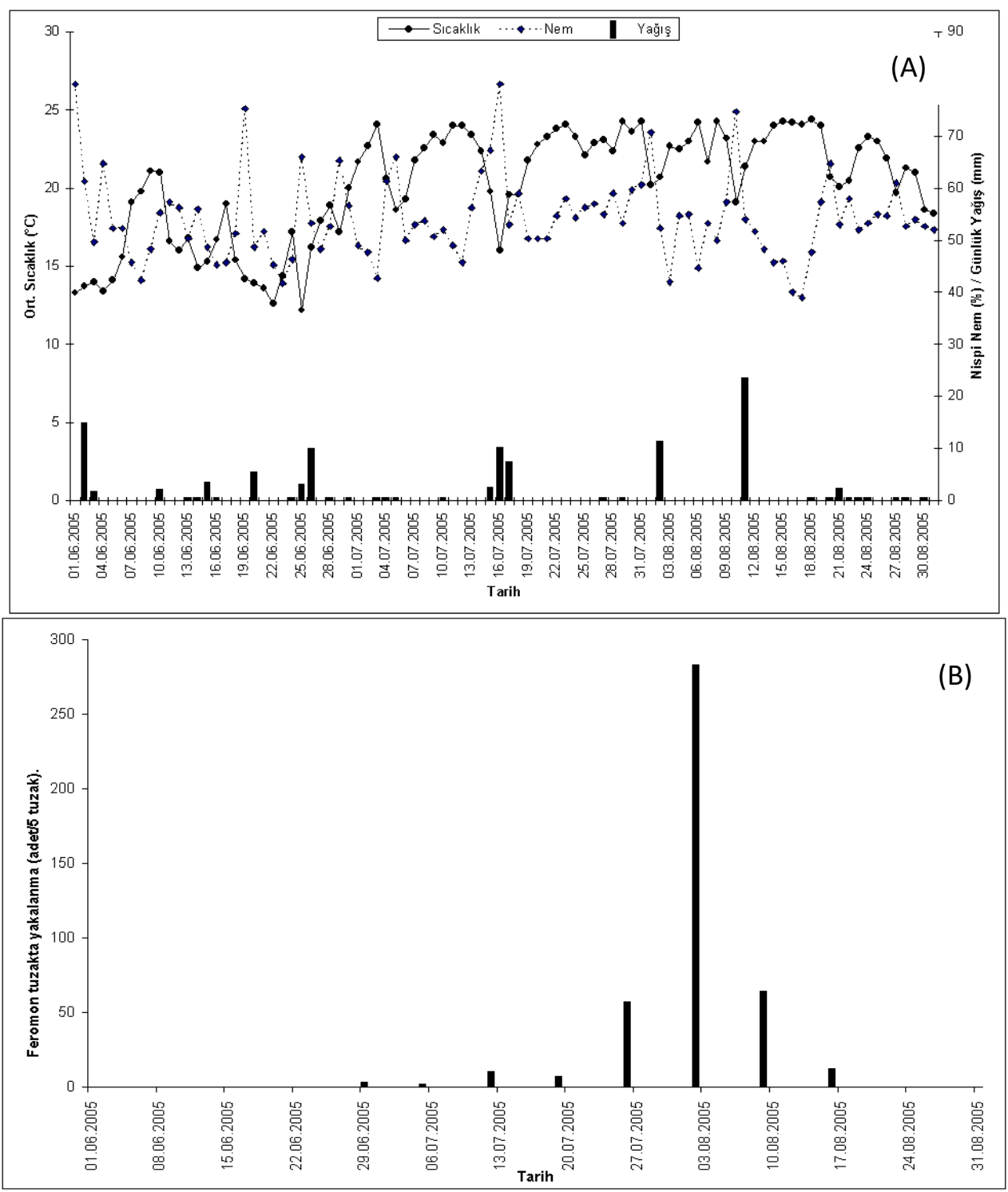

Şekil 4. Çankırı (Orta, Kalfat)'da 2005 yılında ait meteorolojik veriler (A) ile çalışma alanındaki feromon tuzaklarda yakalanan Diprion pini L. ergini sayıları (B)

Tablo 2 ile Şekil 4(A) birlikte incelendiğinde, çalışma alanında ilk kez $D$. pini ergini yakalandığ 1 sirada günlük ortalama sicaklığın $17.2{ }^{\circ} \mathrm{C}$ ve nispi nemin \% 65.3 olduğu; feromon tuzaklarda yakalanmaların gerçekleştiği periyotta ortalama sicaklığın $12.6-24.3{ }^{\circ} \mathrm{C}$ arasında, nispi nemin ise \%40-80 arasında değiştiği anlaşılmaktadır. Söz konusu çalışma alanında yoğun ergin yakalanmaları sirasinda (282 adet) ortalama sicaklığın $20.2-24.3{ }^{\circ} \mathrm{C}$; nispi nemin ise \%52.3-70.3 arasında değiştiği, D.pini uçuşlarının devam ettiği süre boyunca toplam yağış miktarının ise $63.8 \mathrm{~mm}$ olduğu anlaşılmaktadır. 

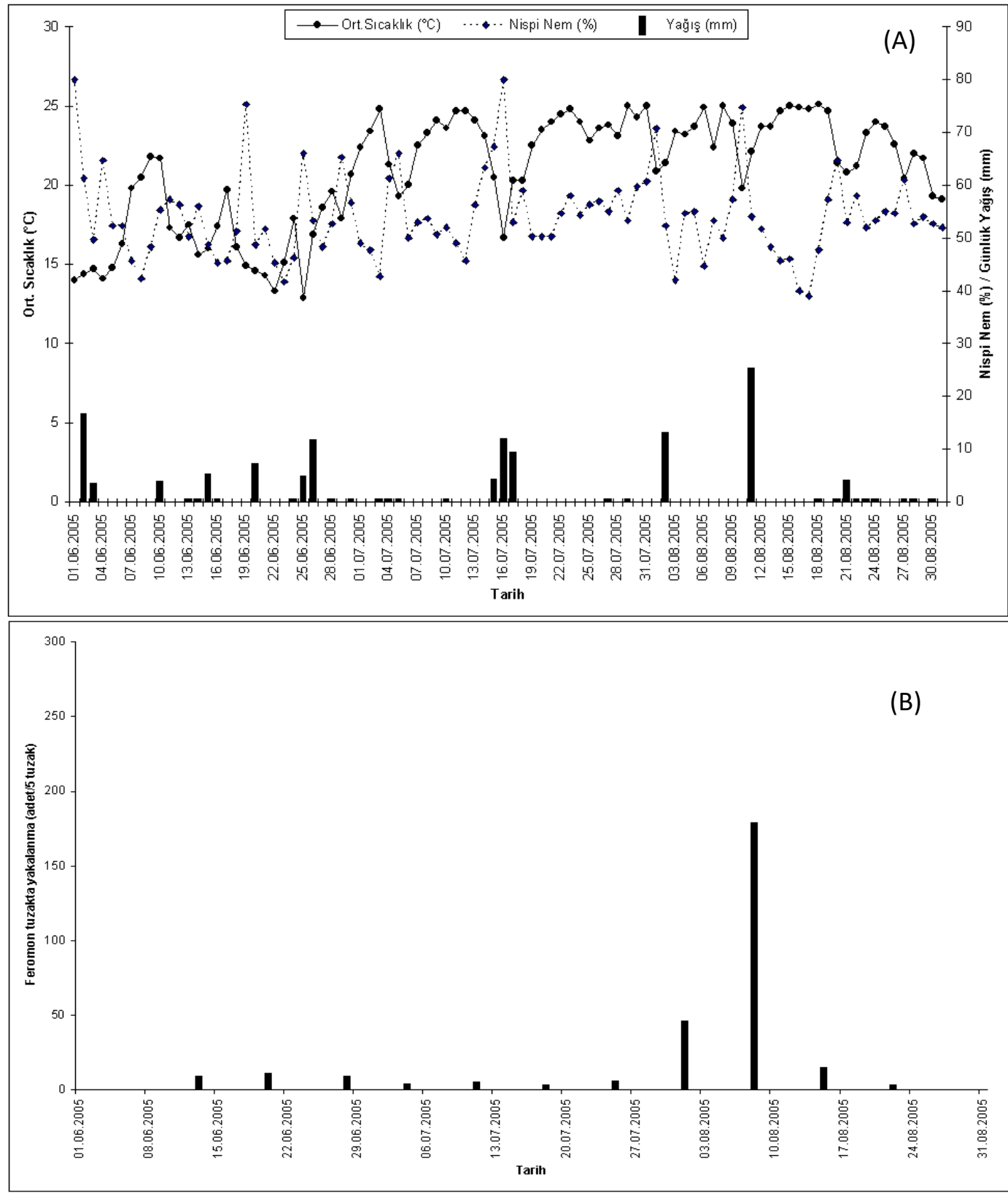

Şekil 5. Çankırı (Kurşunlu)'da 2005 yılında ait meteorolojik veriler (A) ile çalışma alanındaki feromon tuzaklarda yakalanan Diprion pini L. ergini sayıları (B)

Tablo 2 ile Şekil 5(A) birlikte incelendiğinde, Kurşunlu'da ilk kez D. pini ergini yakalandığı sırada günlük ortalama sicaklığın $17.5^{\circ} \mathrm{C}$ ve nispi nemin \% 50.3 olduğu; feromon tuzaklarda yakalanmaların gerçekleştiği periyotta ortalama sicaklığın $12.9-25.1^{\circ} \mathrm{C}$ arasında, nispi nemin ise \%3980 arasında değiştiği anlaşılmaktadır. Söz konusu çalışma alanında en yoğun ergin yakalanmaları sirasında (178 adet) ortalama sicaklığın $21.4-25.0^{\circ} \mathrm{C}$; nispi nemin ise $\% 42$ 55 arasında değiştiği, D.pini uçuşlarının devam ettiği süre boyunca toplam yapış miktarının $94.5 \mathrm{~mm}$ olduğu, yağışı havalarda da uçuşların gerçekleştiği sözü edilen şekilden anlaşılmaktadır.

Şekil 4 ile 5 beraber değerlendirildiğinde, hem Kalfat'ta hem de Kurşunlu'da hava sıcaklığının ortalama $13^{\circ} \mathrm{C}$ ye ulaşmasıyla uçuşların başladığı ve yoğun uçuşların aynı tarihlerde gerçekleştiği görülmektedir. Söz konusu dönemde ortalama sicaklık 12.6$25.1^{\circ} \mathrm{C}$; nispi nemin ise \%39-80 arasinda olduğu (Şekil 4A, 5A); D. pini erginlerinin 
iki uçuş periyodunun bulunduğu; ergin uçuşlarının birinci uçuş periyodunda oldukça zayıf olduğu (Kalfat çalışma alanında 29.06.2005-19.07.2005; Kurşunlu çalışma alanında ise 13.06.2005-18.07.2005 tarihleri arasında), ikinci uçuş periyodunda ise yoğun ergin uçuşlarının gerçekleştiği (Kalfat çalışma alanında 19.07.2005-16.08.2005; Kurşunlu çalışma alanında ise 18.07.200522.08.2005 tarihleri arasında) anlaşılmıştır (Şekil 4B, 5B). Buna göre, feromon tuzaklarda Kalfat (282 adet) ve Kurşunlu (279 adet) orman alanlarında toplam 561 adet D.pini ergininin yakalandığı; yakalanmaların 8.haftasinda Kalfat'ta, 9.haftasinda ise Kurşunlu'da doruk noktasına ulaştığı ve uçuş periyodunun yaklaşı 80 gün sürdüğü anlaşılmıştır.

Feromon Tuzaklarda 2006 Yilında Yakalanan Diprion pini L. Sayıları

Kalfat (Orta) ile Kurşunlu sarıçam orman alanlarında yapılan çalışmada, D.pini erginlerinin feromon tuzaklarda yakalanmalarına ait sonuçlar Tablo 3'te; bunlara ait veriler ise sırasıyla Şekil 6 ve 7'de, iklim verileriyle birlikte verilmiştir.

Tablo 3. 2006 Yılında Çankırı'nın Orta (Kalfat) ve Kurşunlu ilçeleri orman alanlarında feromon tuzaklarda yakalanan Diprion pini L. ergini sayıları

\begin{tabular}{|c|c|c|c|c|c|c|c|c|c|c|c|c|c|}
\hline \multirow[t]{2}{*}{ Tarih } & \multicolumn{5}{|c|}{$\begin{array}{l}\text { KALFAT } \\
\text { Tuzak No }\end{array}$} & \multirow[t]{2}{*}{ Toplam } & \multirow[t]{2}{*}{ Tarih } & \multicolumn{5}{|c|}{$\begin{array}{c}\text { KURŞUNLU } \\
\text { Tuzak No }\end{array}$} & \multirow[t]{2}{*}{ Toplam } \\
\hline & 1 & 2 & 3 & 4 & 5 & & & 1 & 2 & 3 & 4 & 5 & \\
\hline 06.06.2006 & 0 & 2 & 1 & 1 & 0 & 4 & 06.06.2006 & 0 & 0 & 0 & 0 & 0 & 0 \\
\hline 14.06.2006 & 0 & 0 & 0 & 2 & 1 & 3 & 14.06 .2006 & 0 & 0 & 0 & 0 & 0 & 0 \\
\hline 19.06 .2006 & 1 & 8 & 3 & 10 & 3 & 25 & 19.06.2006 & 1 & 1 & 0 & 0 & 1 & 3 \\
\hline 26.06 .2006 & 7 & 54 & 5 & 22 & 8 & 96 & 26.06.2006 & 0 & 0 & 0 & 0 & 0 & 0 \\
\hline 03.07 .2006 & 4 & 18 & 4 & 21 & 5 & 52 & 03.07 .2006 & 0 & 0 & 0 & 0 & 0 & 0 \\
\hline 10.07 .2006 & 6 & 2 & 1 & 5 & 3 & 17 & 10.07 .2006 & 0 & 0 & 0 & 0 & 0 & 0 \\
\hline 17.07.2006 & 20 & 20 & 32 & 62 & 21 & 155 & 17.07.2006 & 1 & 2 & 1 & 2 & 0 & 6 \\
\hline 24.07 .2006 & 5 & 3 & 4 & 10 & 11 & 33 & 24.07.2006 & 4 & 6 & 3 & 6 & 5 & 24 \\
\hline 31.07 .2006 & 8 & 8 & 5 & 4 & 9 & 34 & 31.07 .2006 & 2 & 1 & 1 & 3 & 1 & 8 \\
\hline 07.08 .2006 & 0 & 4 & 0 & 0 & 5 & 9 & 07.08 .2006 & 1 & 0 & 0 & 1 & 0 & 2 \\
\hline 14.08 .2006 & 1 & 3 & 0 & 0 & 4 & 8 & 14.08 .2006 & 0 & 0 & 0 & 0 & 0 & 0 \\
\hline 21.08 .2006 & 0 & 0 & 0 & 1 & 0 & 1 & 21.08 .2006 & 0 & 0 & 0 & 0 & 0 & 0 \\
\hline 28.08 .2006 & 0 & 0 & 0 & 0 & 0 & 0 & 28.08 .2006 & 0 & 0 & 0 & 0 & 0 & 0 \\
\hline 05.09 .2006 & 0 & 0 & 0 & 0 & 0 & 0 & 05.09 .2006 & 0 & 0 & 0 & 0 & 0 & 0 \\
\hline TOPLAM & 52 & 122 & 55 & 138 & 70 & 437 & TOPLAM & 9 & 10 & 5 & 12 & 7 & 43 \\
\hline
\end{tabular}

Tablo 3 incelendiğinde Kalfat (Orta)'taki feromon tuzaklarda ilk kez 06.06.2006 tarihinde D.pini ergini yakalandığ 1 , 21.08.2006 tarihinde son bulduğu görülmektedir. Toplam 155 bireyin yakalandığı uçuş periyodunun 7 . haftasında (17.07.2006) doruk noktasına ulaştığ 1 , uçuşların 76 gün sürdüğü ve bu periyotta 437 adet D.pini'nin yakalandığ 1 aynı tablodan anlaşılmaktadır.
Yine Tablo 3 incelendiğinde; Kurşunlu orman alanındaki feromon tuzaklarda 19.06.2006 tarihinde ilk kez D.pini ergini yakalandığı, 07.08.2006 tarihinde son bulduğu görülmektedir. Aynı yörede, uçuş periyodunun 8.haftasinda (24.07.2006) toplam 24 adet $D$. pini'nin yakalanmasıyla doruk noktasına ulaştığı, uçuşların 49 gün sürdüğü, bu süre içerisinde toplam 43 bireyin yakalandığg görülmektedir. 

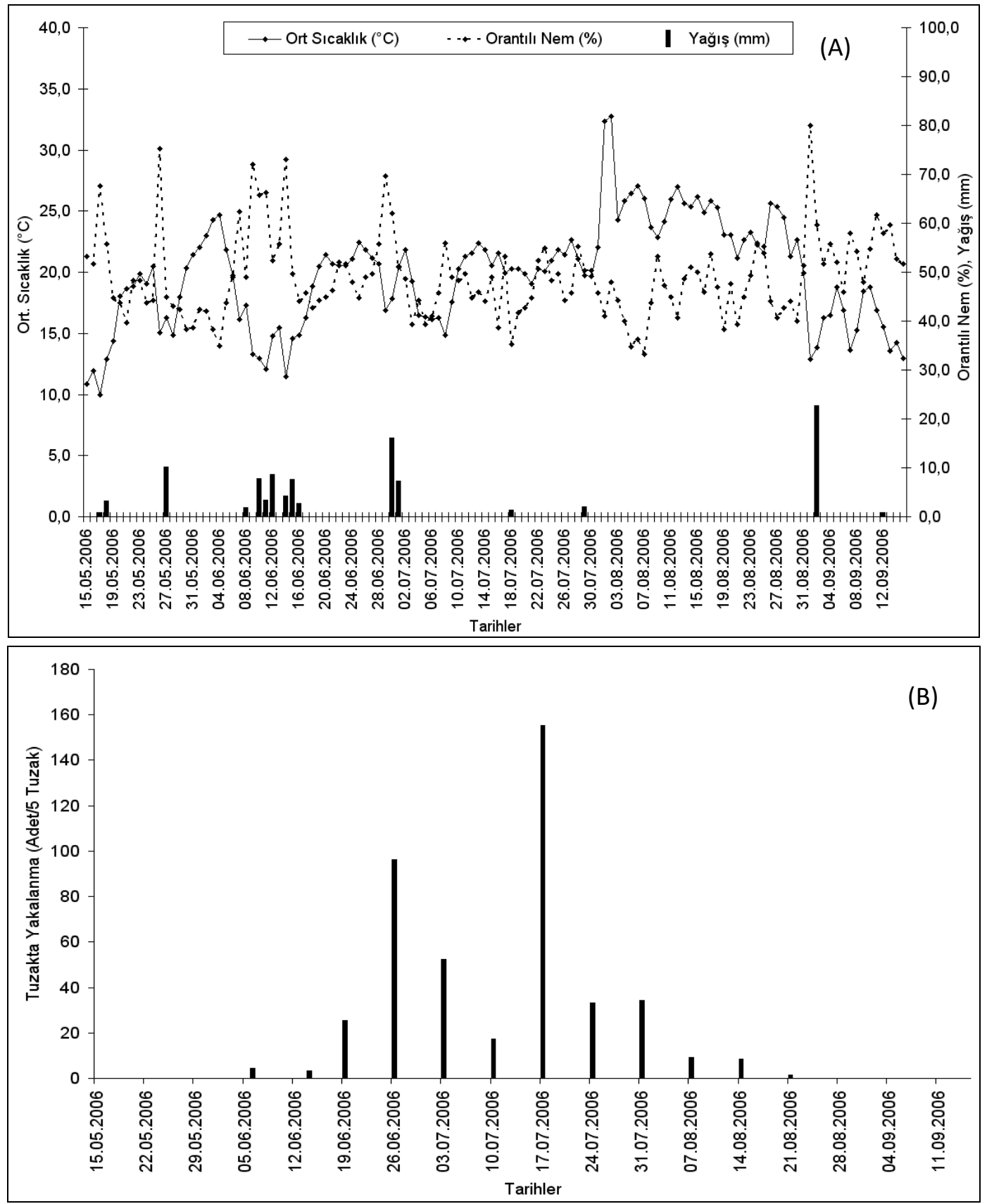

Şekil 6. Çankırı (Orta, Kalfat)'da 2006 yılında ait meteorolojik veriler (A) ile çalışma alanındaki feromon tuzaklarda yakalanan Diprion pini L. ergini sayıları (B)

Tablo 3 ile Şekil 6(A) birlikte incelendiğinde, çalışma alanında ilk kez D.pini ergini yakalandığ 1 sırada günlük ortalama sicaklığın $19.8^{\circ} \mathrm{C}$ ve orantilı nemin $\%$ olduğu; feromon tuzaklarda yakalanmaların gerçekleştiği periyotta ortalama sicaklığın $11.8-32.8^{\circ} \mathrm{C}$ arasında, orantılı nemin ise \%33.3-73.0 arasinda değiştiği anlaşılmaktadır. Söz konusu çalışma alanında yoğun ergin yakalanmaları sirasinda (155 adet) ortalama sicaklığın 20,0$22.4^{\circ} \mathrm{C}$; orant1l1 nemin ise \%38.7-53.3 arasında değiştiği, D.pini uçuşlarının devam ettiği süre boyunca toplam yağış miktarının ise $57.6 \mathrm{~mm}$ olduğu anlaşılmaktadır. 

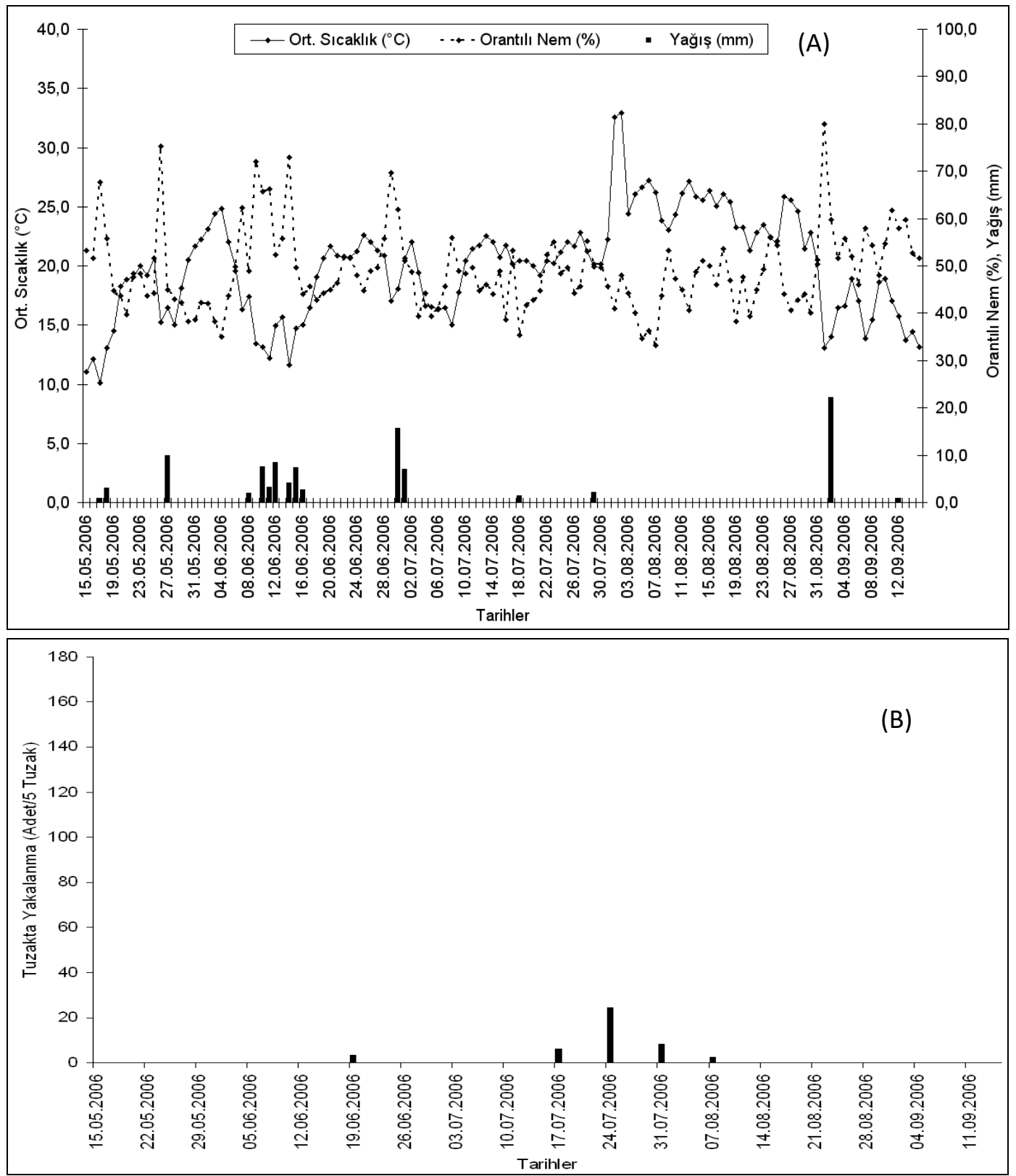

Şekil 7. Çankırı (Kurşunlu)'da 2006 yılında ait meteorolojik veriler (A) ile çalışma alanındaki feromon tuzaklarda yakalanan Diprion pini L. ergini sayıları (B)

Tablo 3 ile Şekil 7(A) birlikte incelendiğinde, Kurşunlu'da ilk kez D.pini ergini yakalandığı sırada günlük ortalama sicaklığın $20.6{ }^{\circ} \mathrm{C}$ ve orantılı nemin \% 44.3 olduğu; feromon tuzaklarda yakalanmaların gerçekleştiği periyotta ortalama sicaklı̆̆ın 15.0-32.9 ${ }^{\circ} \mathrm{C}$ arasinda, orant1li nemin ise \% 33.3-69.7 arasında değiştiği anlaşılmaktadır. Söz konusu çalışma alanında en yoğun ergin yakalanmaları sirasında (24 adet) ortalama sicaklığın 19.2-21.1 ${ }^{\circ} \mathrm{C}$; orantılı nemin ise \%35.3-55.0 arasında değiştiği, D.pini uçuşlarının devam ettiği süre boyunca toplam yapış miktarının $24.2 \mathrm{~mm}$ olduğu sözü edilen şekilden anlaşılmaktadır.

Şekil 6 ile 7 beraber değerlendirildiğinde, hem Kalfat'ta hem de Kurşunlu'da hava sıcaklığının ortalama $20{ }^{\circ} \mathrm{C}$ 'ye ulaşmasıyla uçuşların başladığı ve her iki çalışma alanında da yoğun uçuşların benzer tarihlerde gerçekleştiği görülmektedir. Söz konusu dönemde ortalama sicaklik $19.2-22.4^{\circ} \mathrm{C}$; orantılı nemin ise \%35.3-55.0 arasında olduğu (Şekil 6A, 7A); D. pini erginlerinin iki uçuş periyodunun bulunduğu; ergin uçuşlarının birinci uçuş periyodunda oldukça 
zayıf olduğu (Kalfat çalışma alanında 06.06.2006-10.07.2006; Kurşunlu çalışma alanında ise 19.06.2006 haftasında), ikinci uçuş periyodunda ise yoğun ergin uçuşlarının gerçekleştiği (Kalfat çalışma alanında 10.07.2006-21.08.2006; Kurşunlu çalışma alanında ise 17.07.2006-07.08.2006 tarihleri arasında) anlaşılmıştır (Şekil 6B, 7B). Buna göre, feromon tuzaklarda Kalfat (437 adet) ve Kurşunlu (43 adet) orman alanlarında toplam 480 adet $D$.pini ergininin yakalandığ yakalanmaların 7.haftasında Kalfat'ta, 8.haftasında ise Kurşunlu'da doruk noktasına ulaştığ 1 ve uçuş periyodunun yaklaşık 80 gün sürdüğü belirlenmiștir.

Önceki çalışma dönemlerinde (2004 ve 2005), feromon tuzaklarda yakalanan D. pini ergin sayılariyla birlikte 2006 y1l yakalanmaları değerlendirildiğinde, Kurşunlu'daki çalışma alanında tuzaklarda yakalanan ergin sayısının oldukça azaldığı dikkati çekmektedir. $\mathrm{Bu}$ durum, y1llar itibarıyla iklim koşulları ile doğal baskı unsurlarının değişiminden ve izole sarıçam alanlarında, D. pini feromon tuzaklarının kullanılmasından kaynaklanabileceği kanısını vermektedir.

Yapılan literatür taramasında, D. pini feromon tuzakları kullanılarak bu zararlının izlenmesine yönelik Ülkemizde yapılmış çalışmaya rastlanılmamakla birlikte, son yıllarda Avrupa ülkelerinde yapılan bazı çalışmalar bulunduğu anlaşılmıştır (Anderbrandt ve ark., 1998; LyytikainenSaarenmaa ve ark., 1999; Herz ve ark., 2000; Lyytikainen-Saarenmaa ve ark., 2001; Velez ve ark., 2001; Östrand ve Anderbrandt, 2002). Gerek literatür taramalarında ve gerekse bu çalışmada, D.pini populasyonlarının feromon tuzakları kullanılarak Ülkemizde başarıyla izlenebileceği kanısına varılmıştır.

Çalışma alanlarında D. pini ergin uçuşlarıyla ilgili üç yıllık (2004-2006) veriler birlikte değerlendirildiğinde, Haziran ayının ilk haftası ile Temmuz ayının son haftası arasında (yaklaşık 45 gün) uzun süren birinci uçuş periyodunun bulunduğu, Temmuz ayının son haftası ile Ağustos ayının ortasına kadar süren ikinci periyodun ise daha kısa (10-15 gün) olmakla birlikte, yoğun uçuşların gerçekleştiği belirlenmiştir. D. pini uçuş periyodunun toplamda yaklaşı $50-80$ gün sürdüğü anlaşılmıştır (Tablo 1-3 ile Şekil 27). Sharov (1993) Rusya'da D. pini uçuşlarının iki periyot halinde gerçekleştiğini, birinci uçuş periyodunda uçan erginlerin önceki yıllara ait kokonlardan çıktığını, ikinci uçuş periyodunda uçan erginlerin ise o yılın dölü olduğunu belirtmektedir. Velez ve ark. (2001) ise İspanya'da $D$. pini ergin çıkışlarının iç içe giren iki periyotta olmak üzere iki grup halinde çıktıklarını ve bir döl verdiklerini bildirmektedir. Çalışmamızda elde edilen bulguların, sözü edilen literatür bilgileri ile benzerlik göstediği anlaşılmaktadır.

\section{Çankırı, Orta (Kalfat) ve Kurşunlu İlçeleri Orman Alanlarında 2004-2006 Yillarinda Feromon Tuzaklarda Yakalanan Diprion pini L. Ergin Sayılarının Değişimi}

Kalfat (Orta) sarıçam orman alanına yerleştirilen feromon tuzaklarda yakalanan toplam D. pini sayıları incelendiğinde; 2004 yılında, feromon tuzaklarda yakalanmaların haziran ayının ikinci haftasından başlayarak ağustos sonuna kadar devam etmiş (80 gün), bu süre içerisinde toplam 4434 erginin yakalandığı, yoğun yakalanmaların 9.haftada (1535 adet) gerçekleşmiştir (Tablo 1). Söz konusu çalışma alanında 2005 yılında feromon tuzaklarda yakalanan D.pini sayıları ele alındığında; yakalanmaların haziran ayı sonunda başlayarak ağustos ayı ortasına kadar devam etmiş (48 gün), bu süre içerisinde toplam 430 adet ergin yakalanmış, yoğun yakalanmalar 8.haftada (282 adet) gerçekleşmiştir (Tablo 2). Aynı çalışma alanında 2006 yilında feromon tuzaklarda yakalanan D.pini sayıları ele alındığında ise yakalanmaların haziran ayının ilk haftasından başlayarak 7.hafta sonuna dek devam etmişi (76 gün), bu süre içerisinde toplam 437 adet erginin yakalanmış, en yoğun yakalanmalar ise temmuz ayı ortasında gerçekleştiği (155 adet) saptanmıştır (Tablo 3).

Kurşunlu sarıçam alanına yerleştirilen feromon tuzaklarda yakalanan toplam $D$. pini sayıları incelendiğinde ise; 2004 yılında, feromon tuzaklarda yakalanmaların haziran ayının ikinci haftasından başlayarak ağustos sonuna kadar devam etmiş (82 gün), bu süre içerisinde toplam 1175 erginin yakalanmış, yoğun yakalanmalar 9.haftada (808 adet) 
gerçekleşmiştir (Tablo 1). Söz konusu çalışma alanında, 2005 yılında feromon tuzaklarda yakalanan D.pini sayıları ele alındığında; yakalanmaların haziran ayı ortasından başlayarak ağustos ayının üçüncü haftasının sonuna kadar devam ettiği (70 gün), bu süre içerisinde toplam 279 adet ergin yakalandığı, yoğun yakalanmaların 9.haftada (178 adet) gerçekleştiği anlaşılmaktadır (Tablo 2). Kurşunlu sarıçam alanında 2006 yilında feromon tuzaklarda yakalanan D.pini sayıları ele alındığında ise yakalanmalar haziran ayının üçüncü haftasından başlayarak ağustos ayının ilk haftasının sonuna dek devam etmiş (49 gün) olup bu süre içerisinde toplam 43 ergin yakalanmış, en yoğun yakalanmalar ise 8.haftada (24 adet) gerçekleşmiştir (Tablo 3).

Daha önce, Kalfat ile Kurşunlu sarıçam orman alanında, 2004-2006 yıllar1 arasında feromon tuzaklarda yakalanan D.pini ergin sayılarından yararlanılarak sözü edilen yıllara göre zararlının değişim durumu Şekil 8'de verilmiştir.
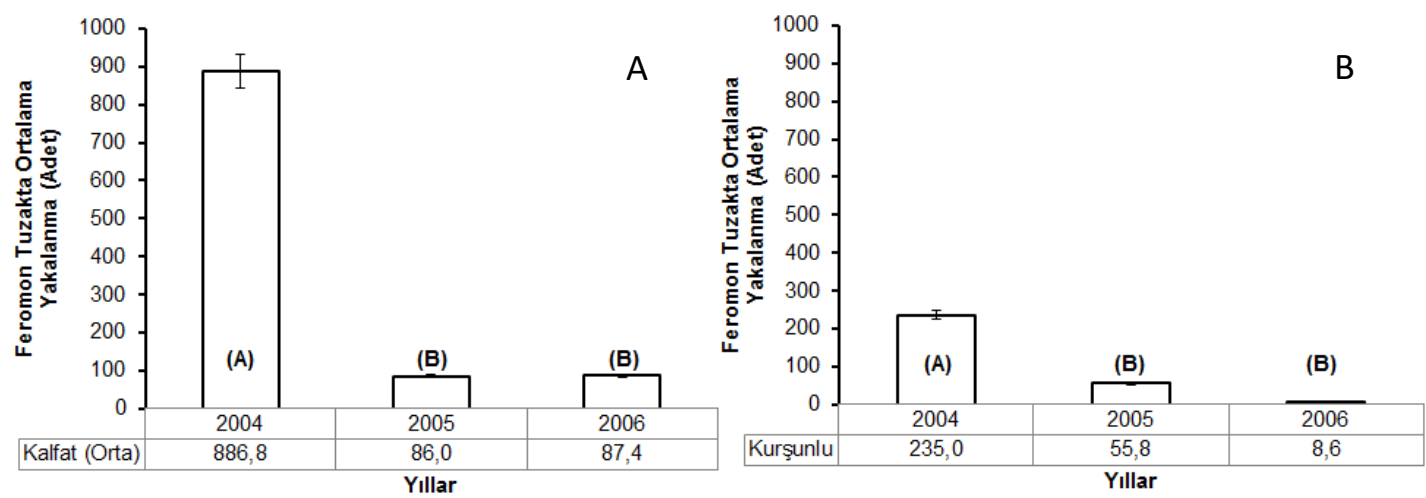

Şekil 8. Çankırı'da Orta (Kalfat) ve Kurşunlu ilçeleri sarıçam orman alanlarında 2004-2006 yılları arasında feromon tuzaklarda yakalanan Diprion pini L. ergin sayılarının değişimi (ergin/tuzak)

Şekil 8(A) incelendiğinde, Kalfat (Orta) sarıçam orman alanında, feromon tuzakta ortalama yakalanan D.pini sayıları yıllara göre ele alındığında; 2004 yılında yakalanan D. pini sayısının (ort. 886.8 adet [A]), 2005 (ort. 86.0 adet [B]) ve 2006 (ort. 87.4 adet [B]) yıllarına göre, önemli düzeyde yüksek olduğu, buna karşın 2005 ve 2006 yıllarında yakalanan ortalama $D$. pini sayıları arasında önemli bir farklılığın bulunmadığ 1 anlaşılmıştır $\left(\mathrm{F}_{(2,12)}=10.377 ; \mathrm{P}<0.05\right)$. Buna göre, 2004 yllinda ilk feromon tuzak uygulamasını izleyen y1llarda, tuzaklarda yakalanan D.pini sayısının azalmış olduğu söylenebilir.

Șekil 8(B) incelendiğinde, Kurșunlu sarıçam orman alanında, feromon tuzakta ortalama yakalanan D.pini sayıları yıllara göre ele alındığında; 2004 yılında yakalanan D.pini sayısının (ort. 235.0 adet [A]) 2005 (ort. 55.8 adet [B]) ve 2006 (ort. 8.6 adet [B]) yıllarına göre, önemli düzeyde yüksek olduğu; buna karşın 2005 ve 2006 yıllarında tuzakta yakalanan ortalama D.pini sayıları arasında önemli bir farklılı̆̆ın bulunmadığ görülmektedir $\left(\mathrm{F}_{(2,12)}=47.114 ; \mathrm{P}<0.05\right)$. Buna göre, 2004 yılında ilk feromon tuzak uygulamasinı izleyen y1llarda, tuzaklarda yakalanan D.pini sayısının azalmış olduğu belirlenmiştir.

Üç yıllık (2004-2006) veriler birlikte değerlendirildiğinde gerek Kalfat (Orta) ve gerekse Kurşunlu çalışma alanlarında D.pini ergin populasyonunun yıllar itibarıyla giderek azaldı $\breve{g} 1$; bu azalmada diğer faktörler (iklim, doğal düşmanların etkinliği, yumurta ile kokon yoğunluğunun azalması vb.) yanında her iki çalışma alanının da izole durumda bulunmasinın, kitlesel yakalamalarda etkili olabileceği kanısını vermektedir.

\section{Sonuç ve Öneriler}

$\mathrm{Bu}$ çalışma neticesinde elde edilen sonuç ve öneriler aşağıda verilmiştir. 
- D. pini ergin uçuşlarının, hava sicaklığının ortalama $13^{\circ} \mathrm{C}$ 'nin üzerine çıktığı Haziran ayının ilk haftasında başlayarak Ağustos'un 3. haftası sonuna kadar devam ettiği anlaşılmıştır. Buna göre $D$. pini' nin toplam 50-80 gün süren iki uçuş periyodunun bulunduğu; bunlardan birincisinde ergin yoğunluğu düşük olmakla birlikte uzun bir periyodu kapsadığ 1 , ikinci uçuş periyodunun ise daha kısa sürdüğ̈ ve yakalanan birey sayısının yüksek düzeyde gerçekleştiği belirlenmiştir. Yoğun uçuşların gerçekleştiği ikinci uçuş döneminin, genellikle Temmuz ayının son haftasından başlayarak Ağustos'un ikinci haftasına kadar (8-9.hafta) sürdügü ortaya konulmuştur.

- Çalışmanın yürütüldüğ̈̈ 2004-2006 yılları arasında Kalfat çalışma alanında feromon tuzaklarda, yıllar itibarıyla sirasiyla 4434, 430 ve 437 adet; Kurşunlu çalışma alanında ise yine yıllar itibarıly 1175,279 ve 43 adet olmak üzere toplam 6798 adet D.pini ergininin yakalanmıştır. $\mathrm{Bu}$ durum, tuzak yönteminin sözü edilen zararlının popülasyon seyrinin izlenmesinde başarıyla kullanılabileceğini açıkça göstermektedir.

Sonuç olarak; D.pini popülasyon seyrinin türe özgü feromon tuzaklarla izlenebileceği; izole alanlarda feromon tuzak kullanılması durumunda, zararlının popülasyon yoğunluğunun azaltılabileceği gibi, mücadele zamanının yönlendirilmesinde de yararlanılabileceği kanısına varılmıştır.

\section{Teșekkür}

$\mathrm{Bu}$ çalışmanın yürütülmesini destekleyen TÜBİTAK TOVAG çalışma grubuna teşekkürlerimizi sunarız.

\section{Kaynaklar}

Chen, G. F., Zhang, Q., Li, Z. Y., Miao, Z. W., Wang, L. Z., Anderbrandt, O. 1987. A preliminary study on the sex pheromone of Diprion jingyuansis Xiao et Zhang. Chinese Journal of Biological Control, 13 (2), 61-64.

Daskalova, I., Kitin, B. 1973. Growth and Condition of Pinus nigra Plantations After Attack by Diprion pini. Naucni Trudove, Vissh
Lesotekhnicheski Institut,Sofiya Gorsko Stopansto, 19 161-170.

Glowachka, B., Malinowski, H. 1994. The Activity of Some Acylurea Insects Growth Regulators Against Forest Pest Sawflies (Pamphilidae and Diprionidae). Folia Forestalia Polonica Seria A, Lesnictwo, (36), 79-90.

Herz, A., Heitland, W., Anderbrandt, O., Edlund, H., Hedenström, E. 2000. First use of pheromone traps to detect phenology patterns and density relationships of pine sawflies in German forests. Agricultural and Forest Entomology 2123-129.

Klimetzek, D., Yue, C. F., Kulfan, J., Suslik, V., Zach, P., Kristin, A. 1997. Climate and forest insect outbreaks. Conference on Insects and Environment (5-6 September 1995), 153-157, Zloven, Slovakia.

Konukçu, M. 1999. Ormancılı̆̆ımız. Turkish Forestry. 146,

Lyytikainen-Saarenmaa, P., Anderbrandt, O., Löfqvist, J., Hedenström, E., Högberg, H. E. 1999. Monitoring European pine sawfly population densities with pheromone traps in young pine plantations. Forest Ecology and Management 124 113-121.

Malinowski, H., Glowachka, B. 1992. Chitin Synthesis Inhibitors as Insecticides Against Harmful Forest Insects. Materialy Sesji Institytu Ochrony Roslin, 32 (1), 116-127.

Moiseenki, F. P., Kozhevnikov, A. M. 1976. The Increment of Pine Stands Damaged by Sawflies. Lesnoe Khozyaistvo 279-82.

Öner, N., Şimşek, Z., Kondur, Y., İmal, B., Şimşek, M. 2010. Küresel iklim değişikliği dikkate alınarak kurak ve yarıkurak alanların ağaçlandırılması ve zararlı böceklerle mücadelesine yönelik öneriler (Çankırı ili örneği). III. Ulusal Karadeniz Ormancilık Kongresi (2022.05.2010), 827-838, Artvin.

Östrand, F., Anderbrandt, O. 2002. On the origin of pine sawflies caught in pheromone traps, Use of pheromones and other semiochemicals in integrated production IOBC wprs Bulletin, 258.

Pilt, E. 1986. Effect of Damage by Diprion pini on Height Increment of Grafted Scots Pines in a Seed Orchard. Metsanduslikud Uurimused,Estonian-SSR, 21 73-78.

Serez, M. 1987. Bazı Önemli Kabukböcekleriyle Savaşta Feromonların Kullanılma Olanakları. Karadeniz Teknik Üniversitesi Dergisi, 10 (1-2), 99-131.

Sharov, A. A. 1987. On the Role of Parasites and Diseases in the Dynamics of Abundance of the Common Pine Sawfly - Diprion Pini (Hymenoptera, Diprionidae) in the Rostov District. Zoologiceskii Zhurnal, 66 (1), 66-74. 
Sharov, A. A. 1993. (K. R. M.R.Wagner, Adaptations to Woody Plants), Academic Press, 409-429, San Diego.

Song, C. Y., Li, Z. Y., Huang, J. Y. 1986. Studies on the control on the pine caterpillars with diflubenzuron II. Field Test. Scientia Silvae Sinicae, 22 (1), 38-44.

Supatashvili, A. 1990. Biological Agents Controlling Diprion pini. Zaschita Ratenii Moskva, 6 23-24.

Şimşek, Z. 2004. Kitin Sentezini Engelleyen Diflubenzuron İlacının Sarıçamın Önemli Zararlısı Olan Çalı Antenli Çam Yaprakarısı (Diprion pini L.: Hymenoptera-Diprionidae) Mücadelesinde Kullanım Olanaklarının Araştırılması. Süleyman Demirel Üniversitesi Orman Fakültesi Dergisi Seri: A, 2 48-59.

Şimşek, Z., Kondur, Y. 2006. Çankırı ormanlarının zararlı böcekleri ve mücadele yöntemleri. Gazi Üniversitesi Orman Fakültesi Dergisi, 6 (1), 98-119.

Velez, L., Diez, J. Y., Pajares, J. 2001. Biología de Diprion pini en la Sierra de Francia. III Congreso Forestal Español Publicación: Actas 45-52,

Wassgren, A. B., Bergström, G. 2000. Sex Pheromone of the Pine Sawfly Macrodiprion nemoralis (Hymenoptera: Diprionidae): Identification of $(2 S, 3 R, 7 R, 9 \mathrm{~S})-3,7,9$-Trimethyl2-tridecanol as the Precursor for the Active Pheromone Acetate. Naturwissenschaften, 87 2429. 